\title{
Estimating Household Willingness to Pay for Improved Solid Waste Management: A Case Study of Thu Dau Mot City, Binh Duong
}

\author{
Pham Thi Thuy Trang ${ }^{1}$, Dinh Quang Toan ${ }^{1,2}$ and Nguyen Thi Xuan Hanh ${ }^{1}$ \\ ${ }^{1}$ Falcuty of Resources and Environment, Thu Dau Mot University, Binh Duong, Viet Nam \\ ${ }^{2}$ College of Natural Resources and Environment, Northwest A\&F University, Yangling, Shaanxi 712100, China
}

\begin{abstract}
The main objective of this paper is to investigate the household willingness to pay (WTP) for improved solid waste management in Thu Dau Mot city, Binh Duong by using Dichotomons choice Contingent Valuation Method. A questionnaire was designed to draw a sample of 330 respondents for the study. The results show that mean household willingness to pay for solid waste management system in Thu Dau Mot is about 24 thousand VND/ month/ household, higher than the current fee (20 thousand VND month/ household). The paper used a logistic regression to establish the factor affecting to the household willingness to pay for solid waste management system. The logit results show that those with a higher income and more educated is willing to pay more for improvement in management of their solid waste. Also, more environmental aware the person the more they are willing to pay. Moreover, females are less likely to give a positive response to WTP compare to male.
\end{abstract}

\section{Introduction}

Thu Dau Mot is one of the economic, financial and cultural centres of Vietnam with 28 industrial parks. The continuous growth of economic and population has brought a new challenge to the local government especially in dealing with the issue of municipal solid waste disposal, particularly domestic household wastes. Currently, there are 120 tons domestic household wastes generated per day, with $70 \%$ is collected and $30 \%$ is illegally dumped. Also, further with increase horizontal expansion of Industry Park, it has become very difficult to find adequate waste disposal sites in the future. The city is now facing with many problems regarding pollution and health because the local waste management system cannot cope with the volumes of wastes being generated. One of the approaches has been now considered by local authority is to increase frequency of collecting waste and number of vehicles of collection.

Actually, improving solid waste management is recognized as critical to improve health and promote environmental protection in the developing countries. To establish an effective management project, it is necessary to be contributed by communities who are the primary producers and suffer the effects of unmanaged solid waste. However, currently in Vietnam, policy makers mainly focus on local authorities and private provider while there is still a lack of data on households' demands and their willingness to pay to improve solid waste management system. Therefore, the key research question is how much household are willing to pay for cost-effective delivery of household solid waste management to residential areas and what are main factors influencing their willingness to pay. To estimate the willingness to pay of individuals, one of the techniques used is contingent valuation method (CVM).The contingent valuation method involves asking to a sample of the population about their willingness to pay for the provision of a given good or service [1] [2]. It is found that CVM can be fruitfully used to support the design and implementation of new solid waste management [3].

The purpose of this paper is to apply the CVM approach to find out the monetary value that households willing to attach for an improved solid waste management service in Thu Dau Mot city and determine variables affecting to their willingness to pay.

According to requirement of CVM study, firstly, the respondent should be given detailed information about the current situation of solid waste management to be valued and the hypothetical scenario under which it is improved. Second, a method which elicits respondent's willingness to pay is applied. Third, household demographic and socio-economic characteristics such as age, gender, income, education level are needed to estimate the valuation function for the environmental service [4]. Finally, regression model is used to analyse obtained data to estimate how willingness to pay are related to the respective variables based on theory. The study result of this paper is essential for policy makers to improve solid waste management in Thu Dau Mot city in particular and other city in Vietnam in general.

\section{Methodology}

\subsection{Questionnaire design}


a questionnaire that is the main instrument for collecting data for CVM study is designed with four sections [2].

-Section 1: Information on the household demographic and socio-economic characteristics (age, gender, education level, environmental awareness, family size, monthly income) is interviewed to generate data that may influence the household willingness to pay.

-Section 2: Information about respondents' environmental awareness and challenges regarding current household waste management service in Thu Dau Mot.

-Section 3: Demonstrate general problems of current management service and propose detailed hypothetical scenario of the solid waste management system improved.

-Section 4: Contingent Valuation question designed to estimate willingness to pay for improved solid waste management system in Thu Dau Mot city. Normally, there are three approaches of CVM that willingness to pay can be elicited [1]. In this paper, authors used dichotomous choice CVM approach which individuals were asked the amount of money, called bid level, to state whether they were willing to pay or not by responding "YES" or "NO". Their choice is motivated by discussion in previous sections.

\subsection{Sampling Strategy}

More than 300 samples should be represented for huge population [5]. Therefore, with total 45.000 households of Thu Dau Mot, in total 330 households were selected to interview by using systematic sampling technique which every 10th building in the area was sampled. The next one in the list will be sampling if every 10th building is vacant.

In-person interviews were conducted with one respondent per household. With dichotomous choice (DC) question used in section 3 of the questionnaire, it is expected that the individual will answer "YES" when their WTP is greater than the suggested bid amount. In this study, different sub sample respondents are asked with different bid level. Based on DWEABS model, the authors establish five different bid levels (23000VNĐ, $26000 \mathrm{VNĐ}, 28000 \mathrm{VNĐ}, 30000 \mathrm{VN}$ and 35000VNĐ) [6]. To avoid estimation bias, each sub sample with same number of respondents should be interviewed for each level of bid, so we have a total of 330 observations divided in five sub samples, with approximately the same number of 66 individuals in each sub.

\subsection{Model specification}

Data analysis was done using Stata statistical analysis software programs. With dichotomous structure of the dependent variable WTP, the model can be estimated through a non-linear probability model and the most common one is the logistic regression model. The logistic regression model allows estimate the probability $(\mathrm{P})$ that an event will occur or not through prediction of a binary dependent outcome[7], coded to take the values 1 or 0 for 'yes' and 'no' answer, respectively, from a set of independent variables:

$$
\begin{gathered}
\mathrm{P}=\frac{1}{1+\mathrm{e}^{-\left(\beta_{0}+\beta_{1} \mathrm{X} 1+. .+\beta \mathrm{kXk}\right)}} \\
\mathbf{W T P}=\operatorname{Logit}=\operatorname{Ln}\left(\frac{\mathrm{p}}{1-\mathrm{p}}\right) \\
=\ln \left(\frac{\operatorname{Pr}(\text { yes })}{1-\operatorname{pr}(\text { yes })}\right)=\beta_{0}+\beta_{1} \text { bid }+. .+\beta_{\mathrm{k}} X_{k} .
\end{gathered}
$$

This paper analyses the effect of bid level asked and six selected variables that are explained in Table I on household willingness to pay, so a logistic model is constructed to check the validity and explanatory power of the relevant factors is as follows:

$$
\begin{aligned}
& \mathbf{W T P}=\operatorname{Logit}=\operatorname{Ln}\left(\frac{\operatorname{prob}(\text { yes })}{1-\text { prob }(\text { yes })}\right)=\beta_{0}+\beta_{1} \text { bid }+ \\
& \beta_{2} \text { gender }+\beta_{3} \text { age }+\beta_{4} \text { edu }+\beta_{5} \text { env }+\beta_{6} \text { income }+ \\
& \beta_{7} \text { size }+\varepsilon .
\end{aligned}
$$

where:

$W T P=$ the dependent variable obtained from respondents in the form of "yes" or "no" answer;

$\mathrm{WTP}=1$ if the respondent answers yes and 0 otherwise, $\varepsilon=$ random disturbance term;

$\beta_{\mathrm{o}}$ is the constant term;

$\beta_{1}$ is the bid amount coefficient.

Table 1. Description of explanatory variables.

\begin{tabular}{|c|l|c|}
\hline $\begin{array}{c}\text { Variable } \\
\text { name }\end{array}$ & \multicolumn{1}{|c|}{ Description } & $\begin{array}{c}\text { Type of } \\
\text { data }\end{array}$ \\
\hline Age & $\begin{array}{l}\text { Age of Respondents(number of } \\
\text { year) }\end{array}$ & $\begin{array}{c}\text { Interval } \\
\text { data }\end{array}$ \\
\hline Gender & $\begin{array}{l}\text { Gender of respondent }(1=\text { female; } \\
\text { 0 otherwise) }\end{array}$ & $\begin{array}{c}\text { Nominal } \\
\text { data }\end{array}$ \\
\hline Edu & $\begin{array}{l}\text { Education of Respondent } \\
\text { Number of years spent in the } \\
\text { school) }\end{array}$ & $\begin{array}{c}\text { Interval } \\
\text { data }\end{array}$ \\
\hline Env & $\begin{array}{l}\text { Environmental awareness of the } \\
\text { respondent. Based on answer in } \\
\text { section 2 of questionnaire. }(0= \\
\text { not aware; } 1 \text { fairly aware; } 2= \\
\text { much aware). }\end{array}$ & $\begin{array}{c}\text { Ordinal } \\
\text { data }\end{array}$ \\
\hline Size & $\begin{array}{l}\text { Number of member in the } \\
\text { Household }\end{array}$ & $\begin{array}{c}\text { Interval } \\
\text { data }\end{array}$ \\
\hline Income & $\begin{array}{l}\text { Monthly Income of the Household } \\
\text { (VND) }\end{array}$ & $\begin{array}{c}\text { Interval } \\
\text { data }\end{array}$ \\
\hline
\end{tabular}

Mean household willingness to pay was calculated using the formula given as [7]: Only influence variables are included in the formula:

$$
\operatorname{Mean}(\mathrm{WTP})=-\frac{\alpha \boldsymbol{Z}}{\boldsymbol{\beta}}
$$

$=\frac{-\beta_{0}+\beta_{2} * \text { mean }(X 2)+\beta_{3} * \operatorname{mean}(X 3)+\cdots+\beta_{\mathrm{k}} * \text { mean }(X k)}{\beta_{1}}$

\section{Results and discussion}

\subsection{Demographic and socio-economic factors}


The demographic and socio-economic characteristics of 330 sample respondents in Thu Dau Mot city are showed in Table II.

The female accounted for $59 \%$ while $41 \%$ were male. It is reasonable because women often stay at home more than men due to responsible for household job. The distribution of household size indicates that $91 \%$ of the household have between 1 to 5 members while only $9 \%$ represent those that between 6 to 10 members. The mean household size is about 4 members. The average age of respondents was 48 years. The age range with the highest frequency is $41-50$ years which accounted for $27 \%$ of the respondents. This implies that respondents are in their active age and therefore can work to earn, more income which can affect their decision to pay for improved waste services. The majority of respondents (46\%) had education of high school. The mean years of education in the study area is 8 years which is still not high enough. This may be one of reasons explaining why the majority of respondents $(61 \%)$ in Thu Dau Mot are not aware environment. The average monthly income of household respondents was 9.5 million VND.

Table 2.Demographic and socio-economic characteristics

\begin{tabular}{|c|c|c|}
\hline Demographic factors & Percentage & Mean \\
\hline $\begin{array}{ll}\text { Age } & \\
& \leq 30 \\
& 31-40 \\
& 41-50 \\
& 51-60 \\
& \text { above } 60\end{array}$ & $\begin{array}{c}8.79 \\
20.01 \\
27.28 \\
23.65 \\
20.27\end{array}$ & 48.09394 \\
\hline $\begin{array}{l}\text { Gender } \\
\quad \text { Male }=0 \\
\text { Female }=1\end{array}$ & $\begin{array}{l}40.91 \\
59.09\end{array}$ & 0.5909091 \\
\hline $\begin{array}{ll}\text { Edu } & \\
& 1-6 \\
& 7-12 \\
& 13-16\end{array}$ & $\begin{array}{l}38.78 \\
45.57 \\
15.65\end{array}$ & 8.469697 \\
\hline $\begin{array}{l}\text { Env } \\
\qquad \begin{array}{l}0=\text { not aware } \\
1=\text { fairly aware } \\
2=\text { much aware }\end{array}\end{array}$ & $\begin{array}{l}61.21 \\
28.48 \\
10.30 \\
\end{array}$ & 0.4909091 \\
\hline $\begin{array}{ll}\text { Size } & \\
& 1-5 \\
& 6-10 \\
\end{array}$ & $\begin{array}{c}91 \\
9 \\
\end{array}$ & 4.075758 \\
\hline $\begin{array}{l}\text { Income } \\
<10.000 .000 \\
10.000 .000-20.000 .000 \\
\text { Above } 20.000 .000\end{array}$ & $\begin{array}{c}51.51 \\
46.07 \\
2.42\end{array}$ & 9578788 \\
\hline
\end{tabular}

\subsection{Logistic regression analysis}

The logistic regression results are presented in Table III. We found that multicollinearity is not a serious problem in our dataset. Testing for heteroskedasticity shows no problem. In order to test for the goodness of fit, the Pseudo R2 and linktest was used. The pseudo $\mathrm{R}^{2}$ is 67.5 , which implies that $67.5 \%$ of the variation in the probability of being willing to pay or not is explained by the variables included in the model.

\subsection{Determinants of willingness to pay}

An important aspect to check when using contingent valuation data is that individuals should be sensible to the bid amount, so we expect that as the bid amount goes up the proportion of individuals that give a positive answer goes down. As expected, our data show that the proportion of positive answers goes down as the bid amount goes up, presented in Table IV.

Table 3.The logistic regression results

\begin{tabular}{|c|c|c|c|}
\hline Variables & Coefficient & Standard error & Significant \\
\hline Age & 0.0126626 & 0.0180913 & 0.484 \\
\hline Gender & -1.883937 & 0.4669733 & $0.000 *$ \\
\hline Edu & 0.4234707 & 0.0677565 & $0.000^{*}$ \\
\hline Env & 2.519017 & 0.4205125 & $0.000^{*}$ \\
\hline Size & -0.0134297 & 0.1554821 & 0.931 \\
\hline Income & $2.14 \mathrm{e}-07$ & $6.28 \mathrm{e}-08$ & $0.001 *$ \\
\hline Bid & -0.0003129 & 0.0000657 & $0.000 *$ \\
\hline Cons & 1.796039 & 2.069628 & \\
\hline \multicolumn{3}{|c|}{$\begin{array}{l}\text { Statistic Summary } \\
\text { No. of Obs } 330 \\
\text { Logi-likelihood } \quad-72.135473 \text { Pseudo } \\
67.5 \% \\
\text { LR Chi2 299.92Prob }>\text { Chi2 } 0.0000\end{array}$} & $\begin{array}{l}\text { Significance } \\
\text { Level } \\
\text { * Significance } \\
\text { at } 1 \% \\
\end{array}$ \\
\hline
\end{tabular}

Table 4.Total number of respondents in each level of bid

\begin{tabular}{|c|c|c|c|c|c|c|}
\hline WTP & 23 & 26 & 28 & 30 & 35 & Total \\
\hline Yes & 37 & 28 & 27 & 27 & 13 & 132 \\
\hline No & 29 & 38 & 39 & 39 & 53 & 198 \\
\hline Respondents & 66 & 66 & 66 & 66 & 66 & 330 \\
\hline
\end{tabular}

The logit results showed that age of respondents and household size do not significantly influence the probability of answering "YES" of respondents to the bid price asked. This relationship was not expected by many researches because people with significant age are often likely to take care for their environment [4] [8]. And in some cases, the more number of people in the household, the more willing the household will appreciate a clean environment.

On the other hand, monthly income, education, environmental awareness and gender of households are statistically significant at $1 \%$.Particularly, the positive sign of the coefficient on income indicate that the relative probability of a 'yes' increases with income, which is consistent with economic theory that indicates that income is positively related with demand in general and the same with environmental demand [8]. This is in conformity with the work other researches [4].

Also, educational level is positively related to willingness to pay to improve waste management services. It means that as level of education increases the tendencies to agree and pay for improved services will also go up. The higher the education attained, the higher the probability of the individual's willingness to pay for improved waste disposal services. The same story happens to the environmental awareness which show that individuals who are aware with environment have a greater position towards the willingness to pay for improved solid waste management than those who are not aware. While, the negative sign of gender indicate that females are less likely to give a positive response. 


\subsection{WTP responses}

From logit result, all explainable variables are statistically influence willingness to pay at significant of $1 \%$, except for age of respondents and household size. So, the mean WTP will be calculated without age and household size variables. Using mean values of variables from Table II, we have:

$$
\begin{gathered}
\text { Mean }(\mathrm{WTP})=-\frac{\alpha Z}{\beta} \\
=-\beta_{0}+\beta_{2} * \text { mean }(\text { gender })+ \\
\frac{\left.\beta_{4} * \text { mean }(e d u)+\beta_{5} * \text { mean }(\text { env })+\beta_{6} * \text { mean(income }\right)}{\beta_{1}} \\
=24.141(\mathrm{VND}) .
\end{gathered}
$$

\section{Conclusion}

By using dichotomous choice CVM, the mean household willingness to pay for improved solid waste management in Thu Dau Mot is estimated about 24.000 VND/ household. This level is higher compare to the current management fees (20.000 VND). Household's educational level, environmental awareness, gender and income were noted to significantly influence their willingness to pay. In general, the household are eager for improved solid waste management, so there is plenty of room to increase the fee and acquire sufficient funds to substantially improve waste management in Thu Dau Mot. This result will add to a small but growing body of knowledge to policy maker in determining the socially optimal charges for solid waste services where households would receive planned and properly scheduled waste management services. It is also recommended that the educational campaigns of the various metropolitan, municipal and district assemblies on waste management should be intensified to increase the awareness of households.

\section{References}

1. A.L. Feldma, Introduction to contingent valuation using Stata, Munich Personal RePEc Archive Paper no.41018 (2012)

2. R.C. Mitchell and R.T. Carson, Using Surveys to Value Public Goods: The Contingent Valuation Method, Washington, DC: Resources for the Future (1989)

3. W. Fonta, H.E. Ichoku, K.K. Ogujiuba and J.O. Chukwu, Using a contingent valuation approach for improved solid waste management facility: evidence from Enugu state, Nigeria, J Afr Econ. 17, 2 (2008)

4. T.R. Ashish and D. Uttam, Households Willingness to Pay for Improved Waste Management In Silchar Municipal Area: A Case Study In Cachar District, Assam, Int. J. Human. Soc. Sci. Res. 6, 5 (2013)

5. R. Worthington and T. Whittaker, Scale Development Research A Content Analysis and Recommendations for Best Practices, Couns Psychol 36, 6 (2006)

6. J. Cooper, Optimal Bid Selection for Dichotomous Choice Contingent Valuation Surveys, J. Environ. Econ. Manage. 24, 1 (1993)

7. J. Loomis, T. Brown, B. Lucero and G. Peterson, Evaluating the Validity of the Dichotomous Choice Question Format in Contingent Valuation, Environ. Resour. Econ 10, 2 (1997)

8. N. Aggrey and O.G. Douglason, Determinants of Willingness to Pay for Solid Waste Management in Kampala City, J. Econ Theory 2, 3(2010) 